\title{
Effect of conditions precedent on building contracts
}

Received (in revised form): 14th June 2006

\section{Deborah Osborne, LLB}

is a solicitor within Watson Burton LLP's Construction \& Engineering Department, one of the largest specialist construction legal departments outside London. She acts for developers and main contractors through to design professionals and sub-contractors. Her experience ranges from advising in all aspects of contract procurement through to advice on large scale, high value construction disputes. She has experience of various dispute resolution forums such as the Technology and Construction Court, arbitration and adjudication and mediation.

Correspondence: Deborah Osborne, Watson Burton LLP, 1 St James' Gate, Newcastle Upon Tyne, NE99 1YQ, UK; Tel: + 44 (0)191 2444444; Fax: + 44 (0)191 2444500; E-mail: deborah.osborne@watsonburton.com

\section{Abstract}

This paper provides an overview of how the courts perceive conditions precedent in building contracts together with a comparison between the courts' approach to conditions precedent in insurance contracts and how that differs from the approach taken in building contracts.

Journal of Building Appraisal (2006) 2, 188-192. doi:10.1057/palgrave.jba.2950040

\section{Keywords:}

construction contract, condition precedent, notices, certificates

\section{WHAT IS A CONDITION PRECEDENT?}

A condition is precedent if it provides that the contract or a term or condition within a contract will not be binding until a specified event occurs. Before the occurrence of the specified condition/event, there is no duty on either party to render the principal performance promised by him/her under the agreement or relevant part thereof.

A condition precedent can be express or implied. In the absence of any qualifying, express wording a party may seek to imply a condition precedent. The test for which is laid out in BP Refinery (Westernport) Pty Ltd $v$ Hastings Shire Council (1977) 52 ALJR 20, in which it was stated that to be implied, a condition precedent must be:

- reasonable and equitable;

- necessary for business efficacy;

- so obvious as to go without saying;

- capable of clear expression;

- consistent with any express terms.

\section{NOTICE PROVISIONS IN CONSTRUCTION CONTRACTS}

Conditions precedent occur most commonly in construction contracts in relation to the granting or otherwise of an extension of time. Numerous construction contracts seek expressly to make the giving of a timely notice a condition precedent to the award of an extension of time. Generally, the condition will be drafted into a contract by way of amendment to the standard forms or incorporation in a bespoke contract. But there are standard forms that make a notice a condition precedent. For example, FIDIC Silver 
book, Clause 20.1, which states that 'If the contractor fails to comply with the time limits in relation to submitting claims the time for completion will not be extended and the contractor will not be entitled to additional payment'.

In such cases, the extension of time clause provides that the contractor's entitlement to an extension of time is dependant upon the service of a notice within a stipulated time of any event that causes delay. Failure to comply with the condition precedent in such a case would appear to remove the contractor's entitlement to an extension of time in respect of that particular event which caused delay.

The Australian case of Gaymark Investments $v$ Walter Construction Group (1999)

NTSC 143, however, held that where there is a delay in completion due to an act of prevention by the employer and the contractor does not comply with the notice provisions, although the result is that no extension of time can be granted, the employer could not claim liquidated damages. There is to date no English Authority on this point, although it is a well-established principle that a party will not be permitted to take advantage of its wrongs (Alghussein v Eton College (1988) 1 WLR 587).

It should be noted in passing that if the time is extended so as to compensate the contractor for delay caused by the employer, then the right of the employer to claim liquidated damages is preserved.

Consideration is given below as to how the courts have perceived conditions precedent.

\section{London Borough of Merton v Stanley Hugh Leach (1985) 32 BLR 51}

Lack of notice was examined in the decision in London Borough of Merton $v$ Stanley Hugh Leach (1985) 32 BLR 51, in which the court held that under a JCT 63 contract a contractor who failed to serve a notice as required by the contract did not lose his rights to an extension of time. Merton's contention that written notice from the contractor was a condition precedent to the granting of an extension of time under Clause 23 was overruled by Vinelott J. who held:

\footnotetext{
'The case for Merton is that the Architect is under no duty to consider or form an opinion on the question whether completion of the works is likely to have been or has been delayed for any of the reasons set out in Clause 23 unless and until the contractor has given notice of the cause of a delay that has become "reasonably apparent" or, as it has been put in argument, that the giving of notice by the contractor is a condition precedent which must be satisfied before there is any duty on the part of the architect to consider and form an opinion on these matters. The arbitrator's answer to this question was that "a written notice from the contractor is not a condition precedent to the granting of an extension of time under Clause 23.'
}

Vinelott J. agreed with the arbitrator's stance. He noted that the construction advanced by Merton in effect involves reading the words 'and if in the opinion of the architect' as equivalent to 'then if in the opinion of the architect'. Vinelott J. accepted this as grammatically the most natural way of reading Clause 23. But, he noted that this would lead to consequences that cannot have been intended, that is, that the architect could ignore events that he knows are likely to cause delay beyond the completion date, even though to the knowledge of the architect the contractor is not aware that the progress of the works is delayed. Vinelott $\mathrm{J}$. concluded that a more rational result is achieved if the word 'and' is taken as conjoining two related but independent duties.

But Vinelott J. agreed with the author of Keating on Building Contracts that if no notice or late notice is given by the contractor and in consequence the architect does not 
become aware that the completion of the works is likely to be delayed beyond the completion date the architect can:

'...take into account that the contractor was in breach of contract and must not benefit from his breach by receiving a greater extension of time than he would have received had the architect, upon notice at the proper time, been able to avoid or reduce the delay by some instruction or reasonable requirement.'

\section{Maidenhead Electrical Services Ltd v Johnson Control Systems (1996)}

In the case of Maidenhead Electrical Services Ltd v Johnson Control Systems (1996), Maidenhead were engaged by Johnson's under Johnson's standard terms and conditions. Condition 17 required all claims for payment to be submitted in writing within 10 days of the occurrence from which the claim arose. This condition specifically provided that if no notification was received within 28 days of that date then the claim would be 'automatically invalid'. Condition 7 (e) required a claim for extension of time to be made in writing within 10 days of the occurrence from which the claim arose, but provided no sanction for failure to do so. It was held:

'It seems plain to me that a failure by Maidenhead to comply with the time limits under condition 7 (e) for making a claim does not by reason of that failure render the claim invalid. If that had been the intention, one would have expected to see an expression such as 'shall be automatically invalid' as is found in condition 17.'

\section{Bremer v Handelgelsellschaft $\mathrm{mbH} v$ Vanden Avenne Izegem P.V.B.A [1978] 2 LLR 109}

In the case of Bremer $v$ Handelgelsellschaft mbH $v$ Vanden Avenne Izegem P.V.B.A [1978] 2 LLR 109, the House of Lords held that a notice provision was unlikely to be a condition precedent unless it stated a specific time for delivery of the notice and stated clearly that the rights would be lost in the event that the notice was not given. Lord Salmon said:

\footnotetext{
'Had it been intended as a condition precedent I should have expected the clause to state the precise time within which the notice was to be served and to have made plain by express language that unless the notice was served within that time the sellers would lose their rights under the clause.'
}

\section{City Inn v Shepherd Construction (2003) CILL 2009}

The most recent authority in this area is the Scottish case of City Inn $v$ Shepherd Construction (2003) CILL 2009. In this case, a clause requiring notice to be given for an extension of time was held to be a condition precedent to the contractor's right to be granted an extension of time if the contractor failed to take the steps specified under the relevant clause, then, unless the employer waived the requirements of that clause, the contractor would not be entitled to an extension of time.

The clause in this case was Clause 13.8.1 of a modified JCT 1980, which stated that where, in the contractor's opinion, any architect's instruction would require an adjustment to the contract sum and/or delay to the completion date, the contractor was not to proceed with the instruction unless he had submitted details of any adjustment and the completion date that would be required. The contract provided a five-day period within which matters should be agreed, after which the instruction should either be withdrawn or the architect instruct the contractor to go ahead, in which case, normal contractual provisions would apply. 
The clause concluded with the proviso that if the provisions were not followed the right to an extension of time would be lost.

Despite this, both the architect and, subsequently, the adjudicator awarded extensions of time. It was, however, held by the Inner House of the Court of Session that the clause was to be treated as a 'condition precedent' to the contractor's right to be granted an extension of time.

Shepherd contended that the clause carried consequences with regards to extensions of time arising from procedural matters rather than from their responsibility as contractors and as such amounted to a penalty. The court rejected that argument.

This case provided a clear loss of rights if the contractor failed to notify, however, most standard forms of contract (eg GC Works/1 or the JCT Major Project Form) do not.

\section{IMPORTANCE OF THE CONTENT OF NOTICES IN BUILDING CONTRACTS}

To avoid the risk of losing their rights, contractors and subcontractors alike should ensure that any written notices that are required by the contract are served in a correct and timeous fashion. But this alone may not avoid disputes arising.

Often the source of dispute arises due to the lack of clarity within the notice provision itself, which is often vague as to what is required so as to constitute the requisite 'notice'. Therefore, a contractor or subcontractor may serve a notice that he considers to be a notice, but, in the eyes of the employer is an inadequate notice.

In the case of London Borough Merton $v$ Stanley Hugh Leach Ltd, Vinelott $\mathbf{J}$ commented on the difficulty of defining the extent of the notice that might be said to be required under JCT 1963:

\footnotetext{
'It is possible to imagine circumstances where the briefest and most uninformative notification of a claim would suffice: a case, for instance, where the architect was well aware of the contractor's plans and of a delay in the progress caused by a requirement that the works be opened up for inspection, but where a dispute whether the contractor had suffered direct loss or expense in consequence of the delay had already emerged. In such case the contractor might give a purely formal notice solely in order to ensure that the issue would in due course be determined by an arbitrator when the discretion would be exercised by the arbitrator in the place of the architect.'
}

Many employers are now drafting conditions precedent that require contractors to give notice of intention to claim within days of the circumstances giving rise to the claim, with a further requirement to provide detailed particulars within a further short period.

Some employers have gone further and require contractors, as a condition precedent to entitlement, to make their claims for additional payment in each monthly application for payment, with each application providing full details of any claim.

For these to be successful in their intent, despite City Inn v Shepherd, Salmon's view in Bremer should be borne in mind

\section{CERTIFICATES AS CONDITION PRECEDENT}

All types of certificate may be expressly made condition precedent to payment and whether a certificate is a condition precedent to payment is a question of construction of the contract wording.

In the case of Costain Building \& Engineering Limited v Scottish Rugby Union Plc (1993) 69 BLR 80 Ct of Sess, it was held that on the true construction of the ICE Conditions of Contract, a certificate of the engineer was a condition precedent to the right of the contractor to be paid. 
In practice, if the architect or engineer has exercised his skill and judgment in issuing the certificate, the courts have generally been of the view that the certificate is a condition precedent to the contractor's entitlement to payment.

It should be noted, however, that a contractor may have an immediate right to adjudication, arbitration or litigation to seek to obtain or alter a certificate.

In light of the above, it is clear that there is a degree of flexibility regarding the approach to the use of condition precedents in building contracts.

This contrasts with the position regarding condition precedents in insurance contracts where the general rule of strict compliance applies to the condition precedent. Breach of Condition precedent by the insured entitles the insurer to refuse payment regardless of whether the breach was remedied or whether the insurer has suffered prejudice as a result of the breach.

\section{CONCLUSION}

In their consideration of conditions precedent in construction contracts, the courts have adopted a more flexible approach. In particular with regards to timely notice as a condition precedent to an extension of time.

In the past, the courts appear to have taken the view that conditions precedent were onerous terms, offensive to longstanding principles of English Law and as such have been reluctant to support the loss of rights of a contractor by failure to serve notice in time. But there has been a shift in attitude by the courts outside England and Wales, who appear to be looking at conditions precedent as a commercial bargain entered into with the full knowledge of both parties which should, as a result, be enforced.

It may be, therefore, that the English courts view condition precedents in building contracts being more favourably to the employer in the future.

Bearing this in mind and the fact that employers are drafting ever more rigid requirements in respect of the conditions precedent, perhaps it is time for contractors and sub-contractors to take stock and ensure that prior to entering into any contract containing a condition precedent that they are fully aware of how the provision operates and what they will have to do to comply with the provision in order to secure their position, for example, with regard to an extension of time, or payment. 